\title{
Morfologia i etapy rozwoju parowu w Uściu koło Chełmna
}

\author{
Morphology and stages of gully development in Uść near Chełmno
}

\section{Tomasz Jaworski, Włodzimierz Juśkiewicz}

Katedra Geomorfologii i Paleogeografii Czwartorzędu, Uniwersytet Mikołaja Kopernika, Toruń, tomjaw@umk.pl

Zarys treści: $\mathrm{W}$ artykule przedstawiono wyniki badań geomorfologicznych parowu wykształconego na zboczach Basenu Unisławskiego w Uściu koło Chełmna oraz badań sedymentologicznych osadów występujących w jego dnie i na stożku napływowym. Formy te rozwinęły się w kilku etapach, co zostało udokumentowane wynikami badań cech strukturalno-teksturalnych osadów oraz datowań OSL. Badania te wykazały, że parów jest wykształcony w dnie peryglacjalnej doliny denudacyjnej z czasu późnego glacjału, która była następnie pogłębiona w młodszej fazie okresu atlantyckiego (ok. 6-5 ka BP).

Słowa kluczowe: parów, debrza, spłukiwanie, Basen Unisławski, Dolina Dolnej Wisły

\begin{abstract}
This paper presents results of geomorphological analysis of alluvial fan and gully situated on the slope of the Unisław Basin (Lower Vistula Valley) in Uść near Chełmno as well as results of sedimentological analysis of deposits in these forms. The gully and alluvial fan near Uść were developed in few stages which are confirmed by structural and textural properties of their sediments and by results of OSL dating. Studies have shown that gully was created in the bottom of the denudation valley from Late Glacial, that was deepened later in the younger phase of the Atlantic period (ca 6-5 ka BP).
\end{abstract}

Key words: gully, ravines, sheet wash, Unisław Basin, Lower Vistula Valley

\section{Wstęp}

Charakterystyczną cechą morfologii Doliny Dolnej Wisły jest występowanie w niej kotlinowatych rozszerzeń zwanych basenami (Galon 1934, Niewiarowski 1997). Jednym z takich dolinnych rozszerzeń jest Basen Unisławski o długości 9-10 km i szerokości 6-9 km. Jego dno położone jest na wysokości 23-32 m n.p.m., natomiast sąsiadująca z nim wysoczyzna morenowa sięga 85-95 m n.p.m. Różnice wysokości względnej wynoszą zatem 60-70 m, taką też wysokość ma oddzielająca te powierzchnie strefa krawędziowa o stromych stokach (nachylenia do $60^{\circ}$ ).

Wschodnie zbocza Basenu Unisławskiego (Dolina Dolnej Wisły) są urozmaicone licznymi formami wklęsłymi - suchymi dolinami różnych typów, głównie erozyjnymi, ale także sporadycznie denudacyjnymi (Niewiarowski 1984, 1997). Najliczniejsze są wśród nich doliny erozyjne z szerokim płaskim dnem i stromymi, lecz nie urwistymi zboczami pokrytymi roślinnością, które zwane są parowami. Doliny tego typu wykazują jednak na pewnych odcinkach cechy wąwozu w ścisłym tego pojęcia znaczeniu (por. Klimaszewski 1978, Migoń 2006), a na innych tylko przypominają parów. Ich rozmiary są różne - najdłuższe dochodzą do $2 \mathrm{~km}$ i są rozgałęzione, zaś krótsze mają układ prosty (nierozgałęziony).

Duże parowy są zazwyczaj głębokie i mają bardzo strome zbocza $\left(25-45^{\circ}\right)$. Najgłębsze osiągają przy wylocie do doliny Wisły 30-45 m głębokości. Na zboczach parowów zaznaczają się spłaszczenia, które świadczą o istnieniu kilku faz ich rozwoju. U wylotu tych parowów występują najczęściej stożki napływowe o różnych rozmiarach. Stożki te dokumentują jedynie młodsze fazy ewolucji parowów, bowiem ich objętości są dużo mniejsze niż suchych dolin, których kubatura osiąga przeciętnie od 2 do $4 \mathrm{mln} \mathrm{m}^{3}$. 


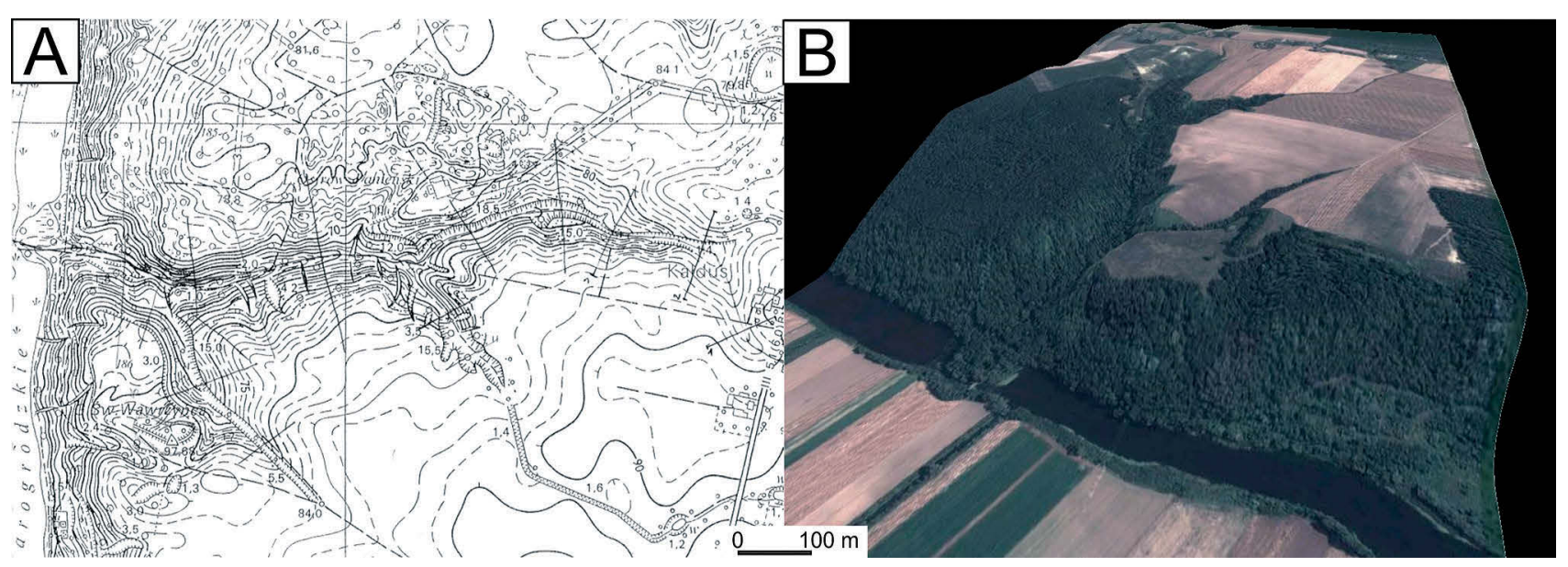

Ryc. 1. Mapa topograficzna wąwozu w Uściu (A) i jego model cyfrowy (B)

Fig. 1. Topographic map of the gully in Uść (A) and its digital model (B)

Przykładem typowego rozcięcia na analizowanym terenie jest parów w Uściu koło Chełmna (ryc. 1).

\section{Metody badań}

W czasie badań terenowych przeprowadzono kartowanie geomorfologiczne parowu w Uściu koło Chełmna wraz $\mathrm{z}$ jego najbliższym otoczeniem $\mathrm{w}$ skali 1:5000, czego efektem jest m.in. opracowana mapa geomorfologiczna (ryc. 2).
Wykonano również podłużne i poprzeczne profile hipsometryczne tego parowu (ryc. 3), których analiza pozwoliła na wyróżnienie kilku jego stref morfologicznych (ryc. 4).

Budowę dna parowu, na poszczególnych jego odcinkach, poznano w oparciu o wkopy (ryc. 5). Umożliwiły one określenie cech litofacjalnych osadów z zastosowaniem kodu litofacjalnego według klasyfikacji Mialla (1977) w modyfikacji Zielińskiego (1995).

Z poszczególnych wkopów, $\mathrm{z}$ warstwowanych serii mineralnych, pobrano próbki do datowania OSL. Uzy-

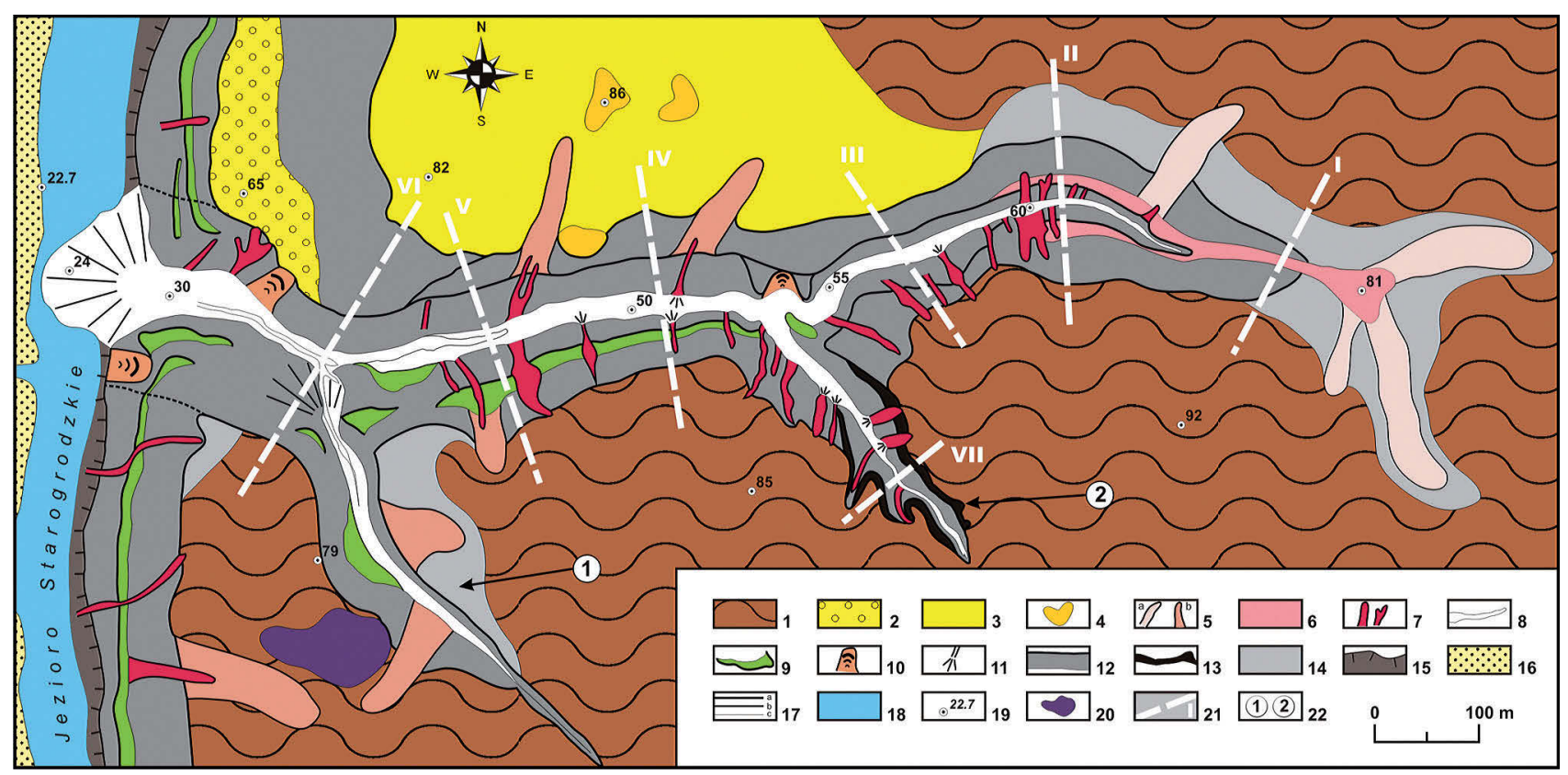

Ryc. 2. Mapa geomorfologiczna parowu w Uściu i jego otoczenia

1 - wysoczyzna morenowa, 2 - terasa sandrowa, 3 - równiny piasków przewianych, 4 - wydmy, 5 - niecki denudacyjne: a) późnoglacjalne, b) holoceńskie, 6 - dno doliny denudacyjnej, 7 - debrza (młode rozcięcia erozyjne), 8 - dno parowu i rozcięcia w dnie, 9 - spłaszczenia na zboczach, 10 - nisze osuwiskowe, 11 - stożki napływowe, 12 - zbocza z załomem górnym i dolnym, 13 - zbocza urwiste, 14 - strefy degradacji, 15 - klify, 16 - dno doliny Wisły, 17 - wysokości załomów: a) powyżej $10 \mathrm{~m}$, b) 5-10 m, c) poniżej $5 \mathrm{~m}, 18$ - starorzecze, 19 - punkty wysokościowe, 20 - grodzisko, 21 - linie profili poprzecznych, 22 - odnogi południowe parowu

Fig. 2. Geomorphological map of gully in Uść and its surrounding

1 - morainic plateau, 2 - outwash terrace, 3 - plains of eolian sands, 4 - dunes, 5 - denudative trought: a) Late Glacial, b) Holocene, 6 - bottom of denudative valley, 7 - ravines (small V-shaped gullies), 8 - bottom of gully, 9 - levels on the slopes, 10 - area of landslides, 11 - alluvial cones, 12 escarpments with upper and lower edges, 13 - sheer slopes, 14 - degradation zones, 15 - cliffs, 16 - bottom of Vistula valley, 17 - hight of escarpments: a) over $10 \mathrm{~m}, \mathrm{~b}) 5-10 \mathrm{~m}$, c) up to $5 \mathrm{~m}, 18$ - oxbow lake, 19 - altitude points, 20 - hill fort, 21 - lines of transverse profiles, 22 - gully southern branches 

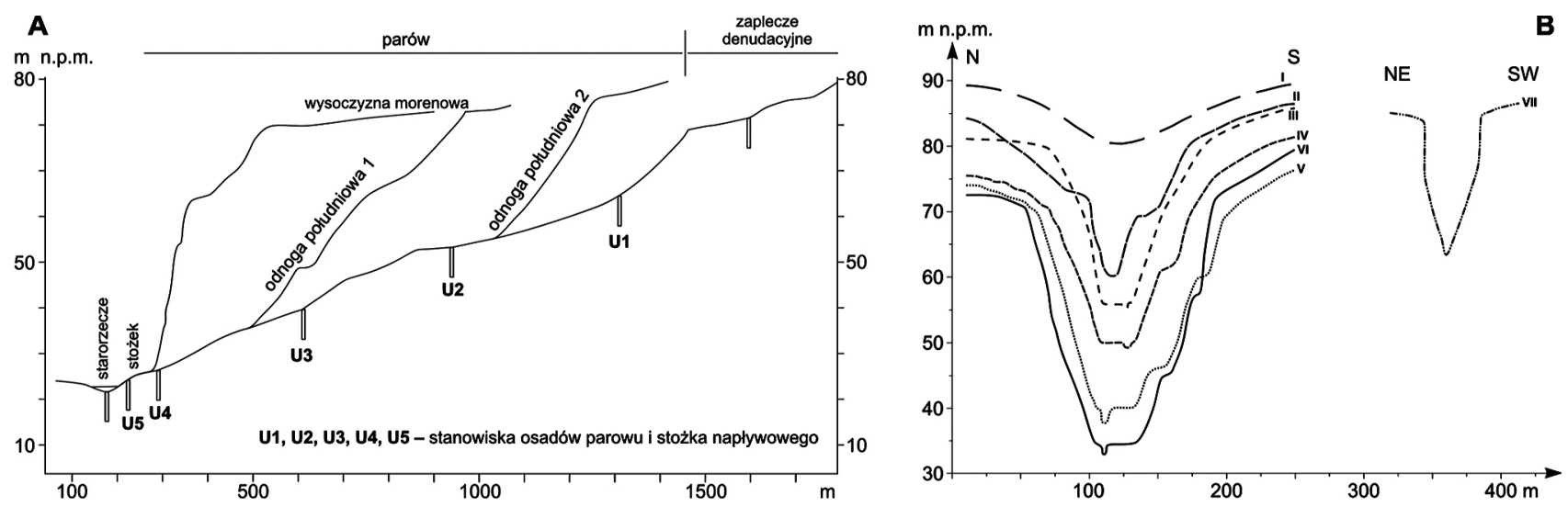

Ryc. 3. Profile hipsometryczne parowu w Uściu

A - profile podłużne, $\mathrm{B}$ - profile poprzeczne

Fig. 3. Hypsometrical profiles of gully in Uść

A - longitudinal profiles, B - transverse profiles

skano daty, które wnoszą nowe informacje o wieku i etapach rozwoju tego typu form na zboczach Doliny Dolnej Wisty.

Prace laboratoryjne obejmowały analizę uziarnienia osadów metodą sitową i za pomocą miernika laserowego. Podstawowe wskaźniki uziarnienia obliczono według Folka i Warda (1957). Dodatkowo określono zawartość materii organicznej metodą strat prażenia w temperaturze $550^{\circ} \mathrm{C}$ oraz zawartość węglanów wapnia metodą Scheiblera.

\section{Cechy morfometryczne parowu}

Parów w Uściu wykształcony jest w dnie dawnej, peryglacjalnej doliny denudacyjnej, uchodzącej do Doliny Dolnej Wisły, której początkowy fragment zachował się na zapleczu suchej doliny (ryc. 2, 3). Od południa ukształtowały się dwie odnogi, które nie mają starszego założenia.

Analizowana forma parowu ma długość około 1200 m, zaś jej denudacyjne zaplecze około 400 m. Dwie odnogi parowu występujące od strony południowej osiągają długość $350 \mathrm{~m}$ (odnoga południowa 1) i $300 \mathrm{~m}$ (odnoga południowa 2). Objętość parowu (wraz z odnogami) wynosi około 2,65 $\mathrm{mln} \mathrm{m}^{3}$, zaś kubatura występującego u wylotu dolinki stożka napływowego jest o 2 rzędy wielkości mniejsza i wynosi około 15 tys. $\mathrm{m}^{3}$.

Wzdłuż profilu podłużnego badanej doliny można wyróżnić następujące odcinki (ryc. 3A, 4):

(i) zaplecze parowu wykształcone w postaci 2 niecek denudacyjnych oraz fragmentu płaskiego dna doliny denudacyjnej (ryc. 4A),

(ii) inicjalne niewysokie urwisko - strome zamknięcie parowu, tzw. headcut (ryc. 4B),

(iii) odcinek początkowy o wąskim, ale wyrównanym dnie (ryc. 4C).

(iv) odcinek środkowy o szerokim wyrównanym dnie (ryc. 4E),

(v) odcinek dolny, wylotowy dolinki o szerokim dnie, ze współczesnym płytkim wcięciem erozyjnym (z odpływem wód gruntowych),

(vi) stożek napływowy.
Uwagę zwraca odnoga południowa 2 (ryc. 2, 3), którą stanowi typowy wąwóz w ścisłym znaczeniu, tj. rozcięcie o wąskim, niewyrównanym dnie oraz o stromych, a w górnej części urwistych zboczach (ryc. 4D).

Kształt profilu podłużnego parowu jest dość zróżnicowany na całej jego długości (ryc. 3A). Na zapleczu analizowanej formy spadek dna jest stosunkowo niewielki i wynosi $1,5-2,0^{\circ}$. Na odcinku górnym parowu spadek dna gwałtownie wzrasta i wynosi około 9,5-10,0 , zaś na odcinku środkowym jest to około $3,5-4,5^{\circ}$ oraz 2,0 $2,5^{\circ}$ na odcinku dolnym.

Górny odcinek parowu ma v-kształtny przekrój poprzeczny oraz wąskie i wyrównane dno. Jego głębokość wynosi tu od 6-8 do 12-14 m. Na odcinku środkowym zbocza osiągają większe nachylenia. Zwiększa się też głębokość parowu, która wynosi tu 20-25 m, a u jego wylotu sięga $40 \mathrm{~m}$. Środkowy i dolny odcinek mają charakter głębokiego parowu (z szerokim, wyrównanym dnem) wciętego w piaszczyste osady międzymorenowe. Na kontakcie piasków międzymorenowych z osadami słaboprzepuszczalnymi stwierdzono występowanie nisz źródliskowych, poniżej których rozpościera się uwodniona, gliniasto-piaszczysta pokrywa osuwiskowo-złaziskowa. Występują tam również nisze osuwiskowe i zalegające poniżej nich zerwy z czytelnym układem warstw o nachyleniu około $25^{\circ}$ (ryc. 2).

$\mathrm{W}$ profilu poprzecznym parów wykazuje niewielką asymetryczność. Generalnie zbocza północne (o ekspozycji południowej) są nachylone pod nieco większym kątem $\left(20-45^{\circ}\right)$ aniżeli zbocza południowe (o ekspozycji północnej) $\left(19-40^{\circ}\right)$.

Zbocza parowu rozcięte są przez liczne debrza (35 form), czyli v-kształtne wcięcia erozyjne o wąskim, często krętym i niewyrównanym dnie (Sinkiewicz 1998), dużym spadku (w niektórych przypadkach do $35-40^{\circ}$ ), zbliżonym do nachylenia zbocza (ryc. 4F). Większość debrzy (25 form) występuje na zboczu południowym (ryc. 1A, 2), co wiąże się z użytkowaniem terenu, bowiem występują tu pola uprawne, podczas gdy obszar przylegający do zbocza północnego w większości porasta las. 


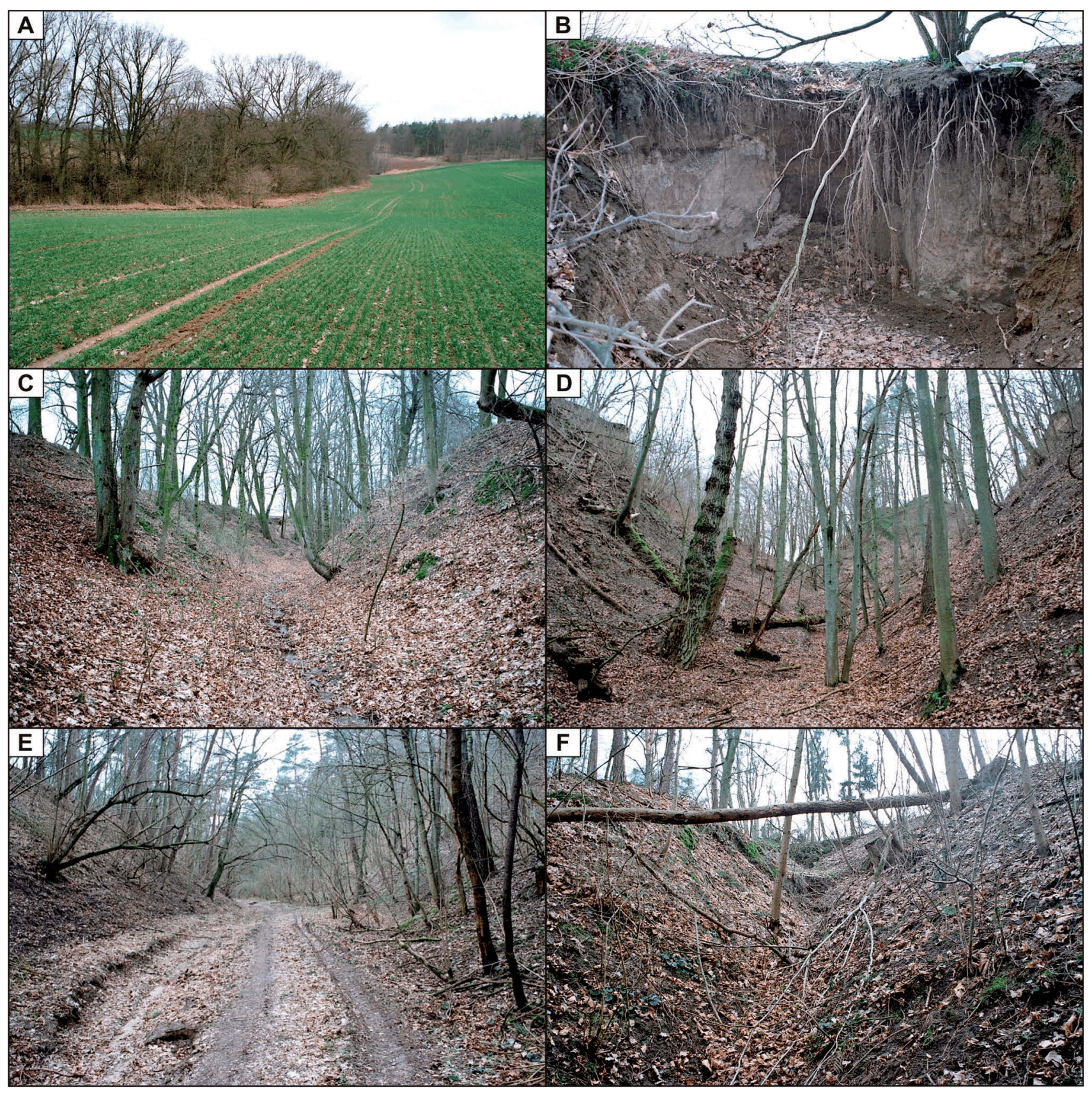

Ryc. 4. Strefy morfologiczne parowu

A - fragment dna dolinki denudacyjnej, B - strome zamkniecie parowu, C - odcinek początkowy parowu, D - odcinek typowego wąwozu, E - odcinek środkowy parowu, $\mathrm{F}$ - debrza

Fig. 4. Morphological zones of gully

A - part of the denudative valley, B - head cut, C - beginning part of the gully, D - typical gully with sheer slopes, E - central part of the gully, F - ravine

W pobliżu wylotu parowu w Uściu zaznaczają się na zboczach doliny Wisły wąskie spłaszczenia o charakterze półek, nie wykazujące jednak wyraźnej ciągłości i zalegające na różnej wysokości. Są to zapewne spłaszczenia denudacyjne nie mające charakteru terasy. U wylotu parowu rozpościera się ponadto niewielki stożek napływowy, który kończy się w Jeziorze Starogrodzkim (starorzecze Wisły). Ma on długość około $180 \mathrm{~m}$ i szerokość u podstawy około 210 m (ryc. 1, 2).

\section{Budowa i wiek dna}

Budowę dna parowu na poszczególnych jego odcinkach poznano w oparciu o wiercenia i wkopy (ryc. 5). Wkopy zostały wykonane na następujących odcinkach parowu: początkowym (stanowisko U1), środkowym (stanowisko U2), dolnym (stanowisko U3) i w stożku napływowym (stanowiska U4 i U5).

$\mathrm{Na}$ odcinku początkowym parowu (stanowisko U1), o wąskim i wyrównanym dnie, występuje seria osadów deluwialnych ze spłukiwania (litofacje Sl, SFl) o miąższości $1,9 \mathrm{~m}$, zalegająca na bruku erozyjnym (litofacje 


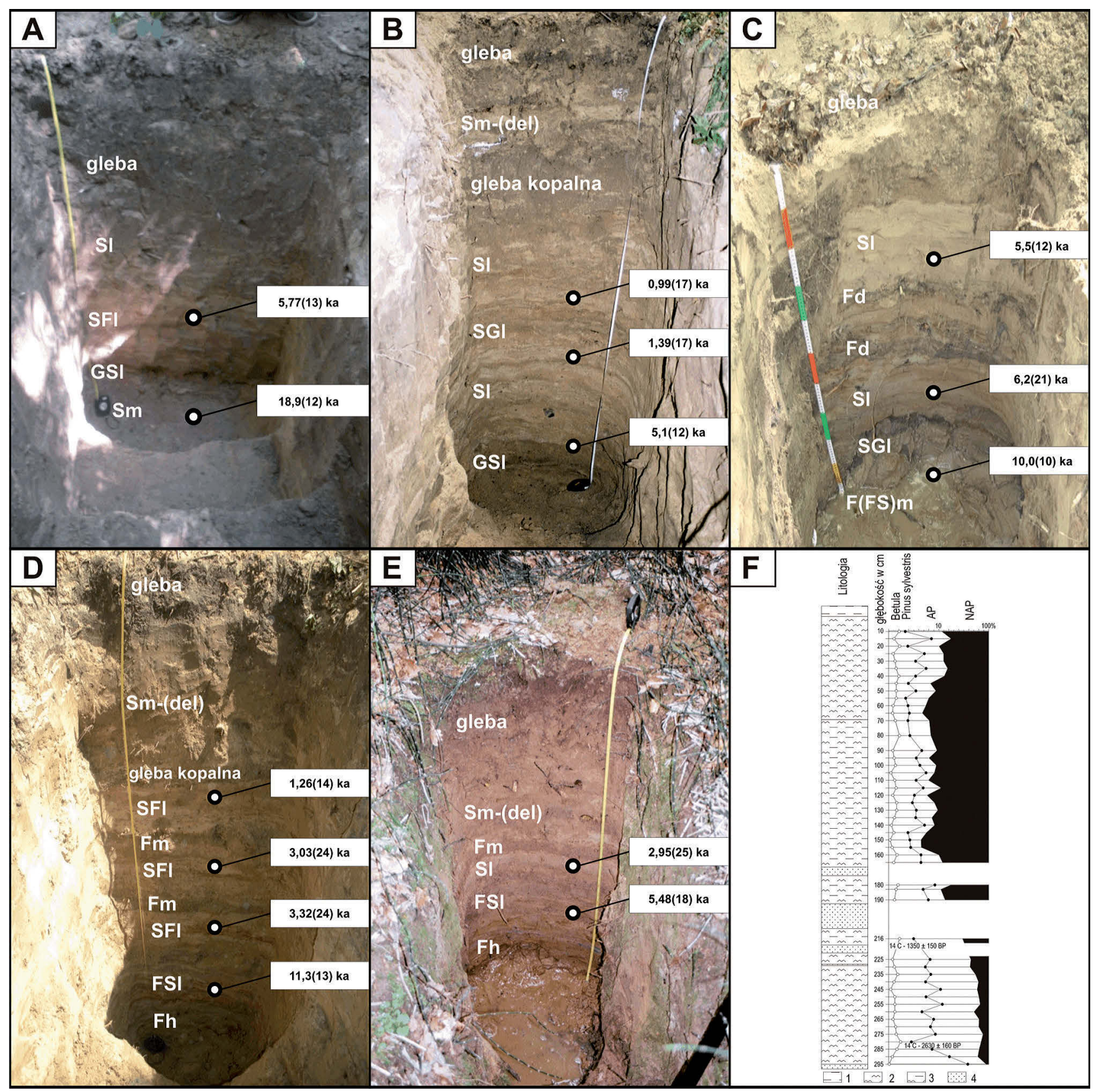

Ryc. 5. Budowa geologiczna dna parowu, stożka napływowego oraz osady dna starorzecza

A - osady w górnej części parowu, stanowisko U1, B - osady w środkowej części parowu, stanowisko U2, C - osady w dolnej części parowu, stanowisko U3, D - osady proksymalnej części stożka napływowego, stanowisko U4, E - osady środkowej części stożka napływowego, stanowisko U5, F - procentowy diagram pyłkowy i litologia osadów z Jeziora Starogrodzkiego

Fig. 5. Geological structure of gullies bottom, alluvial fane and deposits of oxbow lake

A - deposits of upper part of gully, profile U1, B - deposits of central part of gully, profile U2, C - deposits of lower part of gully, profile U3, D - deposits of alluvial fane - proximal part, profile U4, E - deposits of alluvial fane - central part, profile U5, F - percentage pollen diagram and lithology of sediments in the Starogrodzkie Lake

GSl), pod którym występuje litofacja piasków o strukturze masywnej (Sm) (ryc. 5A). Dla osadów stanowiska U1 uzyskano następujące wyniki datowań OSL:

- ponad brukiem erozyjnym - 5,77 ka BP (GdTL-1608), - pod brukiem erozyjnym - 18,9 ka BP (GdTL-1607).

$\mathrm{Na}$ odcinku środkowym parowu (stanowisko U2) w budowie szerokiego i wyrównanego dna stwierdzono serię osadów deluwialnych (litofacje Sl, SGl) o miąższości $2,6 \mathrm{~m}$, powstałych ze spłukiwania. Osady te leżą na bruku erozyjnym (litofacje Gl/GSl). Dla osadów odsłaniających się w profilu U2 uzyskano następujące wyniki datowań OSL (ryc. 5B):

- tuż ponad brukiem erozyjnym, na głębokości około 2,5 $\mathrm{m}-5,1 \mathrm{ka} \mathrm{BP}$ (GdTL-1609),

- na głębokości około 1,7 m - 1,39 ka BP (GdTL-1610),

- na głębokości około 1,4 m-0,99 ka BP(GdTL-1611).

Powyżej zalega gleba kopalna o wieku około $0,9-0,8$ ka

$\mathrm{BP}$, a nad nią najmłodsze deluwia o wieku około $0,2 \mathrm{ka}$ BP. 


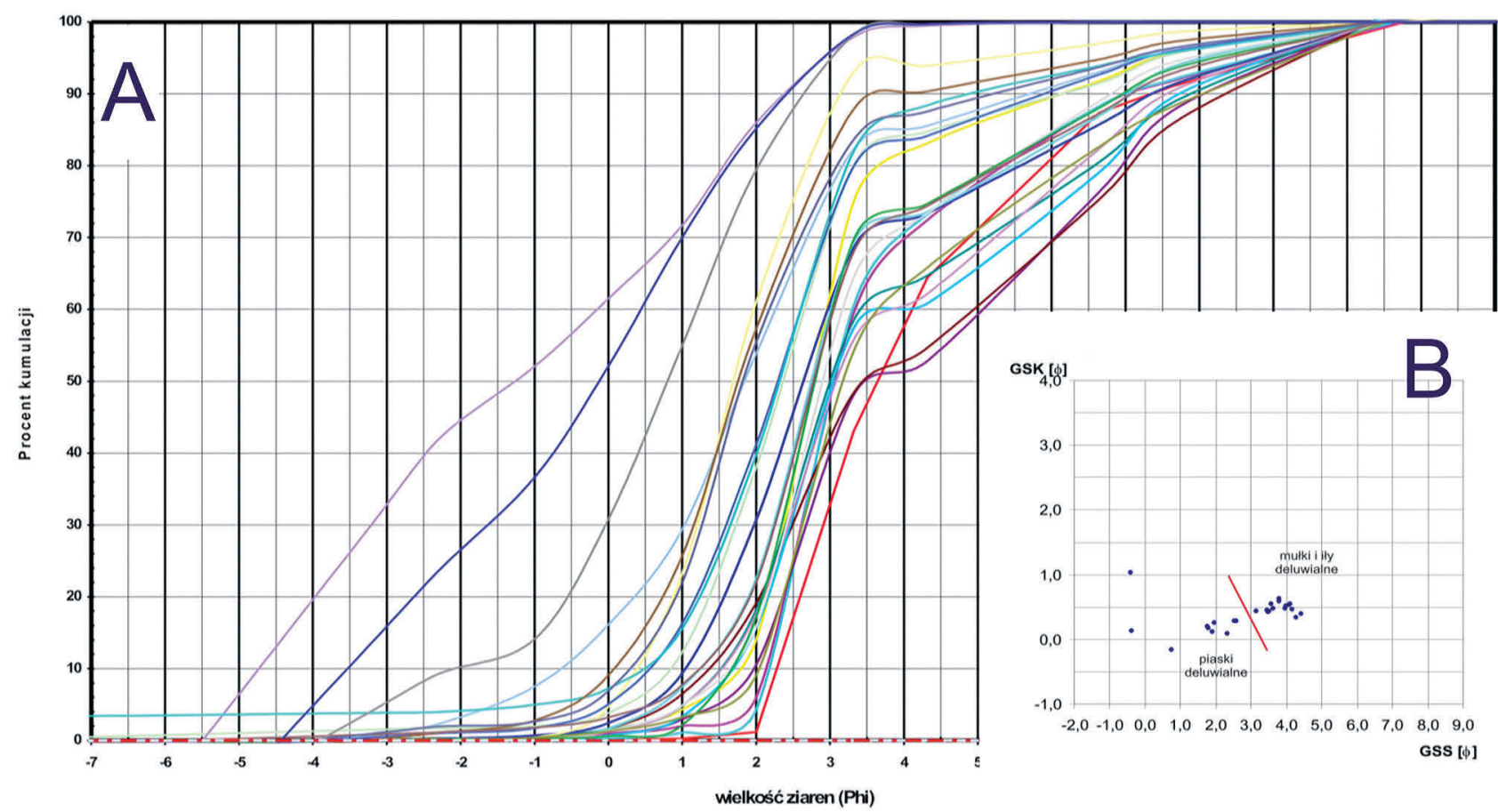

Ryc. 6. Krzywe kumulacyjne osadów (A) oraz zależność pomiędzy średnią średnicą a skośnością rozkładów uziarnienia (B) dla osadów stanowiska U2

Fig. 6. Cumulative curves (A) and relationship between mean grain size and skewness of grain-size distribution (B) of deposits in profile $\mathrm{U} 2$

W profilu osadów środkowej części dolinki typowe jest wyraźne warstwowanie małokątowe, podkreślone przez mułkowe warstwy deluwialne wzbogacone w materię organiczną, odzwierciedlające akumulację drobnych części spławianych w dolnej części dolinki. Cechą charakterystyczną stanowiska U2 jest również wystąpienie dwóch sekwencji o warstwowaniu frakcjonalnym normalnym, co świadczy o etapowości denudacji. Posługując się metodą Vishera (1969), można zauważyć, że rozkłady uziarnienia osadów na stanowisku U2 charakteryzują głównie dwuodcinkowe krzywe typowe dla osadów fluwioglacjalnych i deluwialnych, $\mathrm{z}$ punktem przegięcia FT o wartości około 3,5 phi, z wyraźnym zmniejszeniem zawartości frakcji grubszych (Smolska 2007) (ryc. 6). Jednocześnie zauważalne jest punktowe

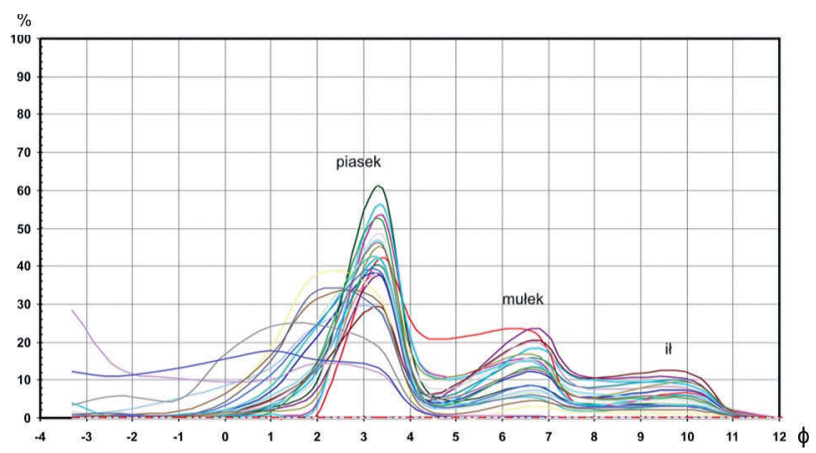

Ryc. 7. Krzywe częstości osadów wypełniających dno parowu w Uściu (stanowisko U2)

Fig. 7. Frequency curves of sediments filled gully bottom in Uść (in profile U2) wzbogacenie w grubsze frakcje (na różnych poziomach) świadczące o przejściowości fazy transportu. $\mathrm{W}$ osadach stanowiska U2 dominuje drobnoziarnisty piasek i gruboziarnisty mułek o słabym i bardzo słabym wysortowaniu.

Największe różnice w zawartości frakcji mułkowo-ilastej, która według Smolskiej (2008) jest najbardziej podatna na denudację, występują pomiędzy profilami w górnej części stoku a strefą tranzytową, gdzie frakcje te są akumulowane. Zauważalne jest ponadto na różnych głębokościach wzbogacenie osadu w grubsze frakcje świadczące o wymywaniu (fazie transportu) oraz frakcje drobniejsze informujące o zmniejszeniu energii transportu (ryc. 7).

$\mathrm{Na}$ dolnym odcinku dolinki o szerokim dnie (stanowisko U3), z wyraźnym wcięciem erozyjnym, stwierdzono serię osadów deluwialnych smugowanych (litofacje Sl, $\mathrm{SFl}$ ), deponowanych ze spłukiwania i zalegających na bruku erozyjnym (litofacje SGl), pod którym występują silnie uwodnione osady litofacji FSm (ryc. 5C). Dla osadów stanowiska U3 uzyskano następujące wyniki datowań OSL:

- tuż ponad brukiem erozyjnym, na głębokości około $0,8 \mathrm{~m}-6,28 \mathrm{ka} \mathrm{BP}$ (GdTL-1617),

- na głębokości 0,3 m - 5,5 ka BP (GdTL-1619),

- pod brukiem erozyjnym, na głębokości 1,1 $\mathrm{m}$ - 10,0 ka BP (GdTL-1618).

Do osadów proksymalnej części stożka napływowego (stanowisko U4) należy seria drobnoziarnistych osadów deluwialnych (litofacje FSl/SFl/Sl) o miąższości 1,8 m, zalegająca na silnie uwodnionych osadach litofacji $\mathrm{Fh}$ 

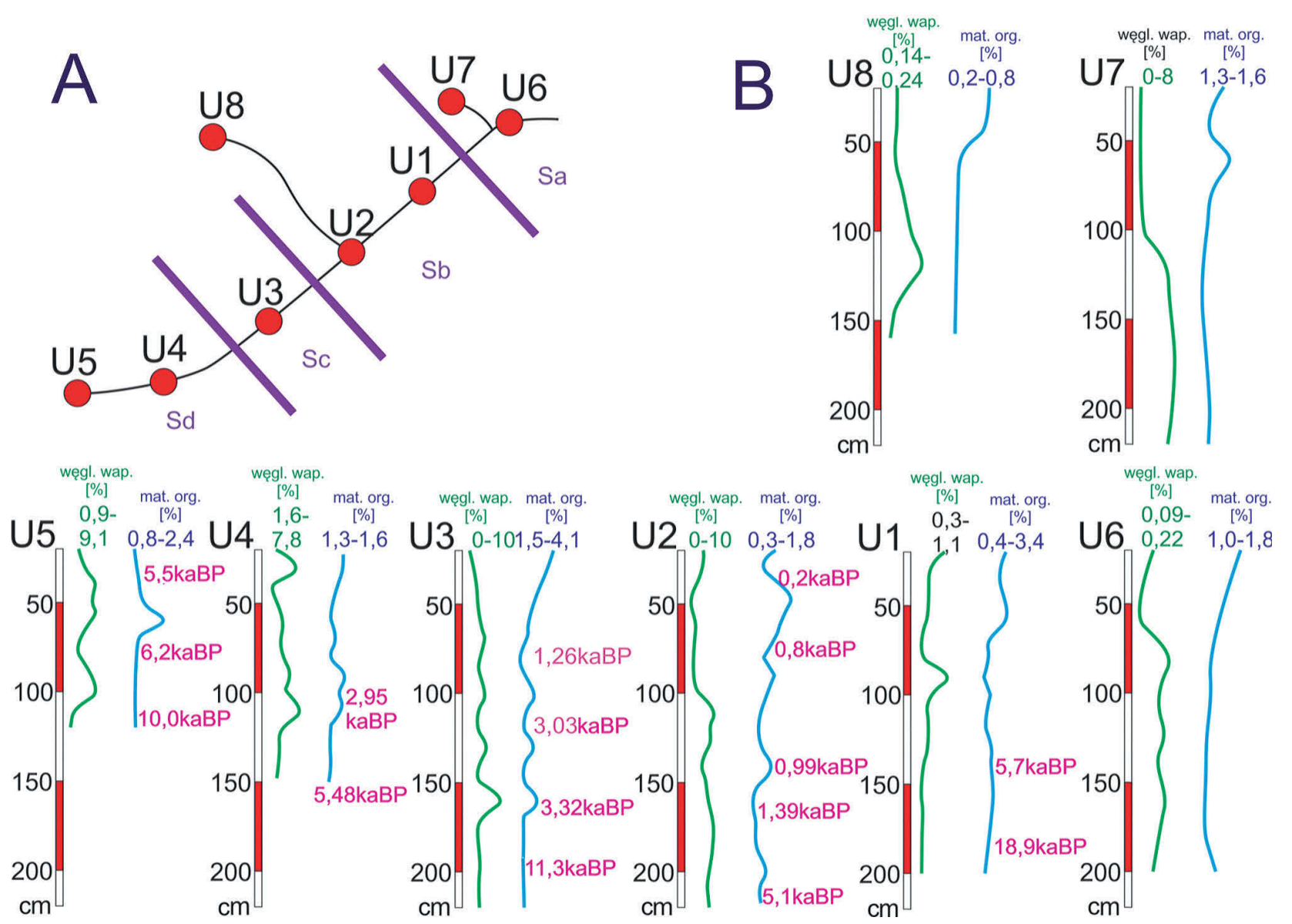

$1,0,4-3,4$

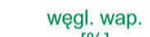

$[\%]$

mat. org

[\%]

Ryc. 8. Zawartość materii organicznej i węglanu wapnia

A - lokalizacja profili badawczych U1-U8, Sa - strefa wymywania, Sb - strefa tranzytowa z przewagą kumulacji, Sc - strefa tranzytowa z przewaga wymywania, Sd - strefa kumulacji z przewagą rozmywania; B - udział materii organicznej i węglanu wapnia w osadach profili U1-U8

Fig. 8. Content of organic matter and carbonates

A - localization of profiles U1-U8, Sa - elution zone, Sb - transit zone with a predominance of accumulation, Sc - transit zone of advantage elution, $\mathrm{Sd}$ - accumulation zone, with a predominance of blurring; B - contribution of organic matter and carbonates in deposits of profiles U1-U8

(ryc. 5D). Dla osadów stanowiska U4 uzyskano następujące wyniki datowań OSL:

- na głębokości 1,9 m - 11,3 ka BP (GdTL-1612),

- na głębokości 1,5 m-3,32 ka BP (GdTL-1613),

- na głębokości 1,2 m-3,03 ka BP (GdTL-1614),

- na głębokości 0,8 m-1,26 (14) ka BP (GdTL-1784).

Osady środkowej części stożka napływowego, zidentyfikowane na stanowisku U5 położonym kilka metrów od brzegu starorzecza, są reprezentowane przez deluwia o miąższości co najmniej 1,6 m (ryc. 5D). Uzyskano dla nich następujące wyniki datowań OSL:

- na głębokości 1,6 m - 5,48 ka BP (GdTL-1615),

- na głębokości 1,0 m-2,95 ka BP (GdTL-1616).

Ponadto $\mathrm{w}$ starorzeczu położonym $\mathrm{W}$ sąsiedztwie stożka napływowego występuje seria osadów związanych $\mathrm{z}$ jego funkcjonowaniem o miąższości prawie $3 \mathrm{~m}$ (Noryśkiewicz 2004) (ryc. 5F). Są to:

- poniżej głębokości 2,95 m - piasek drobnoziarnisty ze żwirem (pochodzenia rzecznego),

- 2,30-2,95 m-mułek jeziorny,

- 2,16-2,30 m - warstwy piasku drobnego z przewarstwieniami iłu mułkowatego,
- 0,70-2,16 m - ił mułkowaty z kilkucentymetrową warstwą piasku,

- 0,0-0,7 m-mułek.

Wyniki analizy zawartości materii organicznej i węglanów wapnia $\mathrm{w}$ osadach stanowisk położonych $\mathrm{w}$ dnie parowu wskazują na ich zmienną koncentrację. $\mathrm{Z}$ tego względu na obszarze i w osadach analizowanego parowu wydzielono strefy: $\mathrm{Sa}$ - wymywania, $\mathrm{Sb}$ - tranzytu z przewagą kumulacji, Sc - tranzytu z przewagą wymywania oraz $\mathrm{Sd}$ - kumulacji z przewagą rozmywania (ryc. 8).

Zaleganie stosunkowo grubej pokrywy osadów deluwialnych wypełniających dolinę $\mathrm{w}$ utrwalonym przez roślinność dnie parowu świadczy o zahamowaniu współczesnych procesów podłużnego wynoszenia deluwiów przez wody płynące. Zaznacza się tu jedynie wąskie wcięcie erozyjne, odprowadzające wody gruntowe oraz wody po większych ulewach i po roztopach. Na odcinku dolnym wcięcie to jest większe - wykazuje 2,5-3,0 m szerokości, okoł 1,0-1,5 m głębokości i odprowadza wody z pobliskich źródeł. Powstały ciek jest również wcięty w stożek napływowy i wpływa do Jeziora Starogrodzkiego. 


\section{Podsumowanie}

Osady podłoża deluwiów zalegające pod brukiem erozyjnym w dnie parowu w Uściu mają wiek około $18 \mathrm{ka} \mathrm{BP,} \mathrm{co}$ oznacza, że uformowanie parowu musiało być procesem młodszym. Deluwia leżące z kolei powyżej bruku erozyjnego wskazują, że w okresie atlantyckim (pomiędzy 6 a 5 ka BP) doszło do formowania się doliny i stożka napływowego uchodzącego do jednego z ramion Wisły. Jednakże większa część tego stożka (dystalna) została rozmyta na skutek erozji rzecznej. Stąd też określeń wiekowych dla stożków napływowych nie można przypisywać wszystkim, które występują w strefie krawędziowej Basenu Unisławskiego, na co zwracał uwagę Nowaczyk (1991). Dopiero schyłek okresu subborealnego, około 3,0-2,6 ka BP (wyniki datowania OSL ze stożka i datowania C-14 materii organicznej ze starorzecza), wskazuje na koniec sedymentacji rzecznej i początek sedymentacji jeziornej. W tym okresie w starorzeczu odkładał się mułek o małej zawartości substancji organicznych i węglanów (Noryśkiewicz 2004). W otoczeniu starorzecza rosły wówczas lasy liściaste (olsy i łęgi), a na zboczach doliny Wisły grądy z dębem, grabem, lipą i wiązem. Ślady działalności człowieka obserwowane palinologicznie związane są z ludnością kultury łużyckiej we wczesnej epoce żelaza. Kolejny etap rozwoju parowu zaznaczył się w osadach ze starorzecza kilkoma przewarstwieniami piasku. Spokojna sedymentacja mułków i mułków ilastych została przerwana dopływem wód powodziowych, spowodowanych dużymi opadami. W wyniku tego procesu nastąpiło rozmycie, przemieszczenie oraz redeponowanie osadu na dnie starorzecza (Noryśkiewicz 2004). W warstwach piasku obserwowany jest brak sporomorf. Analiza pyłkowa wykazuje nieciagłość zarejestrowanej tu sukcesji roślinnej. Hiatus ten przypada na starszą fazę okresu subatlantyckiego (wczesne średniowiecze VIII w., ok. 1,35 ka BP), na co wskazują również wyniki datowania OSL wynoszące 1,39 i 1,26 ka BP, pochodzące odpowiednio z serii warstwowanego piasku w środkowej części dna parowu oraz ze stożka napływowego. Jest to początek intensywnych zmian antropogenicznych w szacie roślinnej, związany z odlesieniem i osadnictwem wczesnośredniowiecznym (druga połowa VII w.). Następny etap ewolucji parowu przypada na późniejszy okres wczesnego średniowiecza (X i X/XI w.), kiedy to otoczenie parowu w Uściu było intensywnie użytkowane rolniczo i pastersko. Potwierdzają to wyniki badań archeologicznych świadczące o intensywnym zagospodarowaniu tych okolic - osada średniowieczna w Kałdusie (por. Chudziak 1998), a także wynik datowania OSL $(0,99 \mathrm{ka} \mathrm{BP})$, uzyskany dla warstwy pia- sku pochodzącej z głębokości 1,4 m w środkowej części dna parowu. Pod względem wieku osad ten odpowiada warstwie piasku $\mathrm{w}$ serii mułku ilastego stwierdzonego w dnie starorzecza na głębokości około 1,65 m. Najmłodszy etap ewolucji parowu rejestruje okres nowożytny, w czasie którego silna antropopresja stała się powodem depozycji w starorzeczu czarnego mułku (Noryśkiewicz 2004) oraz osadów deluwialnych (ok. 200 a BP) powyżej gleby kopalnej w środkowej części dna parowu.

\section{Podziękowanie}

Praca finansowana z projektu badawczego N N306 028837.

\section{Literatura}

Chudziak W., 1998. Wczesnośredniowieczny zespół osadniczy w Chełmnie. Acta Archaeologica Pomoranica 1: 227-235.

Folk R.L, Ward W.C., 1957. Brazos River bar: a study in the significance of grain size parameters. Journal of Sedimentary Petrology 27: 3-26.

Galon R., 1934. Dolina dolnej Wisły, jej kształt i rozwój na tle dolnego Powiśla. Prace Instytutu Geograficznego UP 12/13. Poznań.

Klimaszewski M., 1978. Geomorfologia. PWN, Warszawa.

Miall A.D. 1977. A review of the braided-river depositional environment. Earth Science Reviews 13: 1-62.

Migoń P., 2006. Geomorfologia. Wydawnictwo Naukowe PWN, Warszawa.

Niewiarowski W., 1984. Osady czwartorzędowe i rzeźba terenu. W: R. Galon (red.), Województwo toruńskie - przyroda - ludność i osadnictwo - gospodarka. Państwowe Wydawnictwo Naukowe, WarszawaPoznań-Toruń: 47-81.

Niewiarowski W., 1997. Morfogeneza Basenu Unisławskiego. W: L. Andrzejewski (red.), Procesy, formy i osady fluwialne na obszarze młodoglacjalnym Niżu Polskiego. Warsztaty terenowe. ToruńSłupsk, 18-21 czerwca 1997 r., Toruń: 53-57.

Noryśkiewicz B., 2004. Badania palinologiczne osadów limnicznych Jezior Starogrodzkich. W: W. Chudziak (red.), Mons Sancti Laurenti 2. Wczesnośredniowieczny zespół osadniczy w Kałdusie. Studia przyrodniczo-archeologiczne. Wydawnictwo UMK, Toruń: 165-173.

Nowaczyk B., 1991. Wiek i warunki sedymentacji stożków napływowych w zachodniej części Pradoliny Warszawsko-Berlińskiej. W: A. Kostrzewski (red.), Geneza, litologia i stratygrafia utworów czwartorzędowych. Geografia 50: 153-178.

Sinkiewicz M. 1998. Rozwój denudacji antropogenicznej w środkowej części Polski Północnej. Wydawnictwo UMK, Toruń.

Smolska E. 2007. Development of gullies and sediment fans in last-glacial areas on the example of the Suwałki Lakeland (NE Poland). Catena 71: $122-131$.

Smolska E. 2008. Badania sedymentologiczne współczesnych osadów deluwialnych i ich znaczenie w ocenie dynamiki procesów erozji gleby na przykładzie Pojezierza Suwalskiego. Przegląd Naukowy. Inżynieria i Kształtowanie Środowiska 17(2): 202-212.

Visher G.S. 1969. Grain size distributions and depositional processes. Journal of Sedimentary Petrology 39: 1074-1106.

Zielinski T. 1995. Kod litofacjalny i litogenetyczny - konstrukcja i zastosowanie. W: E. Mycielska-Dowgiałło, J. Rutkowski (red.), Badania osadów czwartorzędowych. Wybrane metody i interpretacja wyników. Wydawnictwo WGiSR UW, Warszawa: 220-235. 